\title{
Herbicide Safeners Increase Waxy Maize Tolerance to Nicosulfuron and Affect Weed Control
}

\author{
Lanlan $\mathrm{Sun}^{1}$, Renhai $\mathrm{Wu}^{2}$, Wangcang $\mathrm{Su}^{2}$, Zenggui $\mathrm{Gao}^{1}$ and Chuantao $\mathrm{Lu}^{2}$ \\ 1. Department of Plant Protection, Shenyang Agricultural University, Shenyang 110866, China \\ 2. Institute of Plant Protection, Henan Academy of Agricultural Sciences, Zhengzhou 450002, China
}

\begin{abstract}
Safeners are an important tool used to ensure the safe using of herbicide. This research was conducted to determine the effects of nicosulfuron alone and in combination with herbicide safeners on waxy maize (Zea mays L. var. ceratina Kulesh) injury, as well as on barnyard grass (Echinochioa crus-galli) and large crabgrass control (Digitaria sanguinalis L. Scop). Whole-plant experiments were conducted under laboratory condition, by using post emergence treatment with safeners and nicosulfuron. The results showed that the herbicide safeners isoxadifen-ethyl (IE) and cyprosulfamide (CS) were more effective in reducing waxy maize injury from nicosulfuron than fenchlorazole-ethyl (FE), cloquintocet-mexyl (CM) and mefenpyr-diethyl (MD). Whole-plant dose-response experiments showed that nicosulfuron in combination with IE or CS increased its herbicidal activities against barnyard grass and large crabgrass. To confirm the result, a mixture of IE or CS and nicosulfuron were sprayed on waxy maize in the field, by using a backpack plot sprayer with a flat-fan nozzle. The mixture led to lower phytotoxicity than nicosulfuron alone. The mixture tested did not affect the maize grain weight. The results showed that IE and CS could enhance crop safety and extend the use of nicosulfuron on waxy maize.
\end{abstract}

Key words: Cyprosulfamide, Digitaria sanguinalis, Echinochioa crus-galli, isoxadifen-ethyl, phytotoxicity.

\section{Introduction}

Maize is one of the most widely planted crops in the world and the largest crop in China. It is not only an important source of food, but is also an important feed and industrial raw material. Around 30\% of maize is planted on the North China Plain (NCP) and this represents about $50 \%$ of China's maize output [1]. The NCP has a double cropping system of winter wheat and summer maize. Mostly, the maize is planted without prior tillage after the wheat harvest, and it is not possible to use pre-emergence herbicides because of the lack of water. Nicosulfuron, usually mixed with atrazine, has become one of the most popular post-emergence herbicides in NCP maize fields because of its low cost and effective weed control. However, nicosulfuron phytotoxicity has widely occurred in NCP maize fields. Inappropriate

Corresponding author: Chuantao $\mathrm{Lu}$, professor, research fields: plant disease, weed science and herbicide. application timing, improper usage and dosage, high temperatures and dry weather are thought to be the main cause of the phytotoxicity [2-4]. Some varieties of maize are sensitive to nicosulfuron and crop injury often occurs after application [5-9]. Therefore, there is an urgent need to solve the problem of nicosulfuron phytotoxicity.

Safeners are chemicals that improve crop plant herbicide degradation [10]. Many safeners have been commercially exploited and are widely used to improve crop tolerance to herbicides. Siminszky et al. [11] found that naphthalic anhydride (NA) reduced the herbicidal injury to maize caused by nicosulfuron-terbufos interactions. Robinson et al. [12] showed that BAS-145138 reduced nicosulfuron injury to sweet corn and prevented visible injury from nicosulfuron. The NA and BAS-145138 are applied as a seed-treatment, which reduces their potential as nicosulfuron safeners in China.

Trends toward post-emergence herbicide treatments 
and the use of high-activity herbicide molecules have led to the development of post-emergence applied safeners for winter cereals. A new era in safener research began with the discovery of 1,2,4-triazolcarboxylates. Fenchlorazole-ethyl (FE) was developed as a post-emergence safener against the wheat ACCase inhibitor fenoxaprop-ethyl, which is applied in a tank mixture with the herbicide. Similarly, dihydropyrazol dicarboxylate mefenpyr-diethyl is used against ACCase inhibitors, such as fenoxaprop-ethyl, mesosulfuron and iodosulfuron, in a variety of cereals. The main use of 8-quinolinoxy-acetate cloquintocet-mexyl is against clodinafop-propargyl in wheat. Dihydroisoxazole-carboxylate isoxadifen-ethyl can safen herbicides that have various modes of action. It has been applied to maize in combination with foramsulfuron, but a mixture containing foramsulfuron and iodosulfuron-methyl is also in use. In rice, it can also be used along with fenoxafop-p-ethyl and ethoxysulfuron. Arylsulfonyl-benzamide cyprosulfamide is the latest development in safener research. It protects maize against isoxaflutole pre-emergence and can also be used in maize along with isoxaflutole plus thiencarbazone in pre-emergence and early post-emergence applications [10].

Herbicide safeners improve crop tolerance to herbicides by regulating the expression of genes involved in herbicide metabolism, but not weeds, such as wild oats and crabgrass. However, some weeds are affected by safeners. For example, FE and mefenpyr-diethyl (MD) can reduce fenoxaprop-ethyl efficacy against blackgrass, and in turfgrass, cloquintocet-mexyl (CM) can increase creeping bentgrass tolerance to topramezone [13]. This suggests that the influence of safeners on weed control should be identified before field application.

The aim of this research was to identify effective safeners that reduce nicosulfuron injury in waxy maize and evaluate safener influence on weed control efficacy.

\section{Materials and Methods}

\subsection{Experiment 1: Identification of Candidate Safeners}

This experiment evaluated the ability of various safeners to increase maize tolerance to nicosulfuron. The maize variety was waxy maize Zhenghuangnuo No. 2, which is commonly used on NCP. Waxy maize seeds were planted in plastic pots filled with a 2:1:1 mixture of soil, vermiculite and growth medium. All plants were irrigated as needed to prevent wilt. They were treated when they had reached the 3- to 5-leaf stage. The waxy maize was treated with the different safeners listed in Table 1. Higher than label rates are often used in order to further understand relative crop safety and to evaluate the potential interactions between safeners and maize hybrid sensitivity $[14,15]$. Nicosulfuron effects were evaluated at $90 \mathrm{~g} / \mathrm{ha}$ with or without safener at $15 \mathrm{~g} / \mathrm{ha}$. The treatments were arranged in a completely randomized single factor treatment design with three replications. Comparisons were made to a non-treated control. The safeners in Table 1 were also applied alone to waxy maize at 15 $\mathrm{g} / \mathrm{ha}$ to assess phytotoxicity. They were dissolved in $1 \% \mathrm{v} / \mathrm{v}$ dimethylformamide and then added to the water carrier. The treatments were applied using methods modified from Schulte and Köcher [16]. Nicosulfuron was either applied alone or in combination with safeners (6:1 ratio) to the leaf core of maize plants using a micro syringe. The applied volume per plant was $100 \mu \mathrm{L}$. The herbicides were applied on May 13 and 28, 2014 for experimental 1 and 2. Plant height and fresh weight were evaluated two weeks after treatment (WAT), and the results were transformed into a percentage of the non-treated control.

\subsection{Experiment 2: Dose-Response Experiments}

Large crabgrass and barnyard grass were used in a whole-plant experiment in a glasshouse to determine the herbicidal activities of nicosulfuron. Pre-germinated 
Table 1 Safeners applied to field grown maize in experiment 1.

\begin{tabular}{lll}
\hline Safener $^{\mathrm{a}}$ & Formulation & Manufacturer \\
\hline Cyprosulfamide (CS) & $94.01 \%$ TC & Zaozhuang Lan's Chemical Co., Ltd. \\
Isoxadifen-ethyl (IE) & $98.50 \%$ TC & Changzhou Runfeng Chemical Co., Ltd. \\
Mefenpyr-diethyl (MD) & $95.00 \%$ TC & Hangzhou Udragon Chemical Co., Ltd. \\
Fenchlorazole-ethyl (FE) & $95.00 \%$ TC & Hangzhou Udragon Chemical Co., Ltd. \\
Cloquintocet-mexyl (CM) & $95.00 \%$ TC & Hangzhou Udragon Chemical Co., Ltd. \\
\hline
\end{tabular}

${ }^{\mathrm{a}}$ Safeners were applied with a non-ionic surfactant at $0.1 \% \mathrm{v} / \mathrm{v}$. TC: technical material.

seeds ( 30 seeds per pot) were sown in a $15 \mathrm{~cm}$ diameter plastic pot filled with a 1:1 (v/v) mixture of sand and soil. The soil $\mathrm{pH}$ was 7.4 and the organic matter content was $1.6 \%$. After emergence, the seedlings were thinned to 20 plants per pot. The herbicide treatments were applied to the plants at the 3- to 4-leaf stage using a laboratory sprayer equipped with a flat-fan nozzle that delivered $280 \mathrm{~L} / \mathrm{ha}$ at $230 \mathrm{kPa}$. Then they were then returned to the greenhouse. Nicosulfuron was applied at $0,5,10,20,40,60$ and $80 \mathrm{mg} / \mathrm{kg}$ in combination with safener isoxadifen-ethyl (IE) or cyprosulfamide (CS) at a ratio of 2:1, 4:1 or 8:1 (nicosulfuron:safener). At 3 WAT, every plant in each pot was cut at the soil surface and the fresh weight was measured. The $\mathrm{ED}_{50}$ value was calculated using probit regression analysis [17]. The experiment was a completely randomized design with three replications and the whole experiment was repeated twice.

\subsection{Experiment 3: Field Experiment}

The experiment 1 results showed that the nicosulfuron in combination with $\mathrm{CS}$ and IE warranted further investigation, so field trials were conducted from 2014 to 2015. The field experiments were carried out in a summer maize field located at the Modern Agricultural Science and Technology Demonstration Base, Henan Academy of Agricultural Science, China $\left(35^{\circ} 6^{\prime} \mathrm{N}, 113^{\circ} 65^{\prime} \mathrm{E}\right)$. The soil at the experimental site was a loam with uniform fertility. The site had a flat relief with adequate irrigation and drainage, and the previous crop was wheat. Local farming practice was followed, which meant that the wheat was harvested by combine-harvester and the maize was mechanically planted. The maize was sown on June 19, 2014 and June 23, 2015. Each plot was 3 $\mathrm{m}$ wide by $7 \mathrm{~m}$ long and consisted of four maize rows. The maize variety used in this experiment was Zhenghuangnuo No. 2 in both years.

The CS or IE safeners were applied post-emergence at $15 \mathrm{~g} / \mathrm{ha}$ in combination with nicosulfuron at $60 \mathrm{~g} / \mathrm{ha}$ or $90 \mathrm{~g} / \mathrm{ha}$. Three herbicides were applied at the 3- to 5-leaf stage for maize (July 4, 2014 and July 6, 2015). A weed-free, hand weeded control and a weedy control were established. Nicosulfuron and nicosulfuron-safener combinations were sprayed using a backpack plot sprayer with a flat-fan nozzle (LECHLER 110-015 Green) and calibrated to deliver $450 \mathrm{~L} / \mathrm{ha}$ aqueous solution at $0.2-0.3 \mathrm{MPa}$. The experiments were organized as a complete randomized block design with four replications.

The maize plant height and a visual rating for weed control were evaluated at 7,14 and $21 \mathrm{~d}$ after treatment. The weed control rating was based on a scale of $0 \%-100 \%$, where $0 \%=$ no control and $100 \%$ $=$ mortality. The maize was harvested at physiological maturity (October 10, 2014 and October 12, 2015) and the grain yield was determined by hand-harvesting 10 cobs from the two central rows of each plot.

\subsection{Statistical Analysis}

All of the results were expressed as the mean \pm standard deviation (SD). SPSS Software (version 17.0, SPSS Inv., Chicago, IL, USA) was used to statistically analyze the data, and Duncan's test was used to determine the significant differences among the treatments. $P=0.05$ was used as the statistical 
significance threshold.

All the dose-response data were analyzed using the following probit model as Eq. (1).

$$
Y=a+b X
$$

where, $Y$ is the probit, $a$ is the intercept, $b$ is the regression coefficient and $X$ is $\log _{10}($ dose) [17].

The analysis was performed using SPSS software (Version 13.0, SPSS Inc.) and $\mathrm{ED}_{50}$ values were computed.

\section{Results and Discussion}

\subsection{Identification of Candidate Safeners}

The maize after the nicosulfuron treatment alone showed stunting and yellowing. Fig. 1 shows the effects of nicosulfuron with or without herbicide safeners on the plant height and fresh weight of the maize seedlings. Nicosulfuron applied at $90 \mathrm{~g} / \mathrm{ha}$ reduced plant height and the fresh weight of the maize seedlings to $38.5 \%$ and $14.4 \%$ of the non-treated control at 2 WAT (Fig. 1). These results agreed with the findings reported by Gao et al. [8].

The safeners CS, IE, MD, FE and CM applied alone had no effect on plant height and fresh weight (data not shown). There were varying degrees of protection afforded by the different nicosulfuron and safener combinations. CS and IE reduced waxy maize injury more than CM. Nicosulfuron alone reduced maize fresh weight to $14.4 \%$ of the non-treated control, but application in conjunction with either CS or IE increased fresh weight to $69.9 \%$ and $59 \%$ of the non-treated control, respectively. CM eliminated the reduction in maize fresh weight, but there was no effect of plant height. The MD and FE safeners had no effect on the plant height and fresh weight reduction caused by nicosulfuron. Other researchers have observed that different safeners vary in their ability to protect maize against herbicide injury [18-20] and they found that both BAS-145138 and dichlormid were highly effective as safeners for metazachlor, and BAS-145138 and DKA-24 were equally good safeners for acetochlor.

\subsection{Dose-Response Experiment}

The whole-plant dose-response experiments showed that nicosulfuron in combination with IE or CS increased its herbicidal activities against barnyard

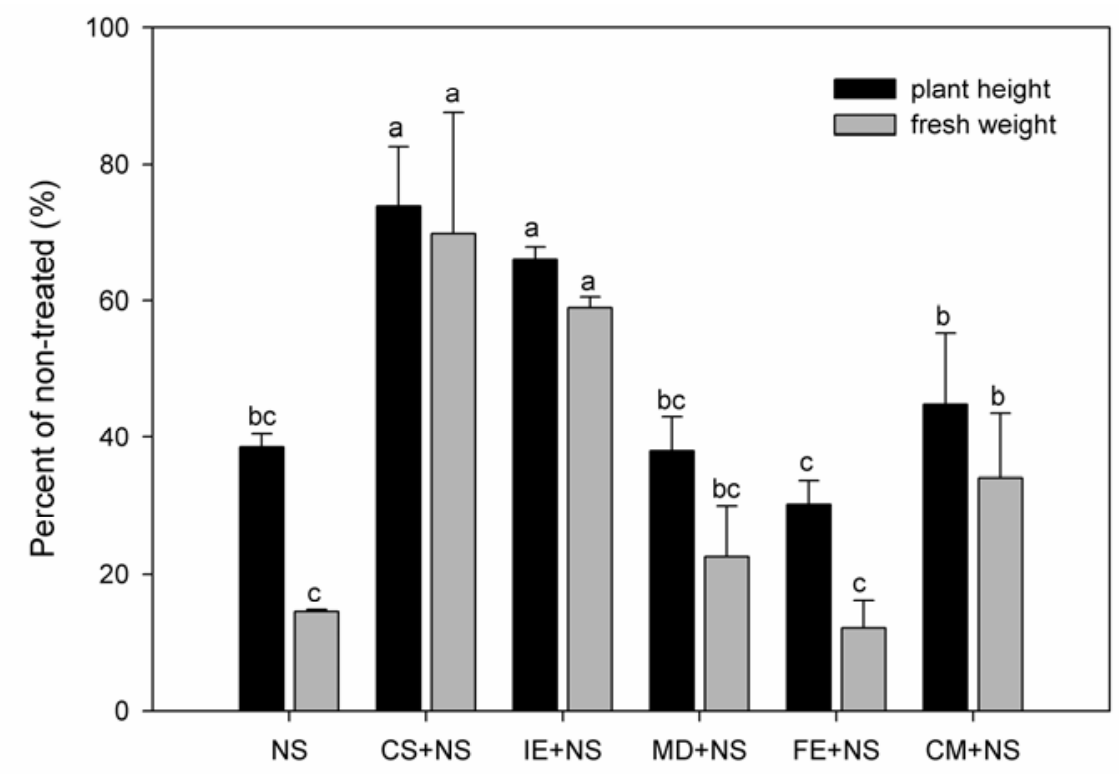

Fig. 1 Plant height and fresh weight of waxy maize at $15 \mathbf{d}$ after treatment.

NS: nicosulfuron; CS: cyprosulfamide; IE: isoxadifen-ethyl; MD: mefenpyr-diethyl; FE: fenchlorazole ethyl; CM: cloquintocet-mexyl.

The same letters in the columns indicate no statistical difference as determined by Duncan's multiple range test $(P<0.05)$. 
grass and large crabgrass. The concentrations of nicosulfuron that resulted in a $50 \%$ growth reduction $\left(\mathrm{EC}_{50}\right)$ was $22.59 \mathrm{mg} / \mathrm{L}$ for the barnyard grass; while for the nicosulfuron combined with IE and CS in different proportions, the $\mathrm{EC}_{50}$ values were 12.03-14.4 $\mathrm{mg} / \mathrm{L}$ and $11.62-15.46 \mathrm{mg} / \mathrm{L}$, respectively (Table 2). When nicosulfuron was applied alone, the $\mathrm{EC}_{50}$ value was $83 \mathrm{mg} / \mathrm{L}$ for the large crabgrass; while nicosulfuron combined with IE and CS in different proportions produced $\mathrm{EC}_{50}$ values of $28-45 \mathrm{mg} / \mathrm{L}$ and 13-33 mg/L, respectively (Table 3). Elmore et al. [21] found that $\mathrm{CM}$ and $\mathrm{MD}$ did not affect pinoxaden efficacy against perennial ryegrass, but reduced efficacy against roughstalk bluegrass. Safeners can also antagonize weed control in cereal crops. MD and FE have been shown to decrease fenoxaprop-ethyl efficacy against blackgrass [22]. However, the combination of fenoxaprop-p-ethyl and MD is registered for blackgrass control in cereals [23]. The data from this study suggested that IE and CS increased nicosulfuron efficacy against barnyard grass and large crabgrass. Therefore, a field experiment was conducted to evaluate nicosulfuron in combination with CS or IE.

\subsection{Field Experiment}

All only nicosulfuron treatments slightly injured waxy maize in both years. The injury symptoms from nicosulfuron were interveinal chlorosis and stunting. This result confirmed the findings reported by Zhang et al. [24]. Table 4 shows that maize injury at 1 WAT for nicosulfuron at the $60 \mathrm{~g} / \mathrm{ha}$ and $90 \mathrm{~g} / \mathrm{ha}$ rates was between grades 2 and 3, and the injury was still observed at 3 WAT. The waxy maize injury caused by nicosulfuron in combination with IE and CS treatments was transient and only observed at 1 WAT. These results indicated that waxy corn injury declined, when the IE and CS were added to nicosulfuron.

At $1 \mathrm{WAT}$, the nicosulfuron at $60 \mathrm{~g} / \mathrm{ha}$ and $90 \mathrm{~g} / \mathrm{ha}$ treatment levels significantly reduced plant height to $69 \%-71 \%$ of the non-treated control, but application in conjunction with either IE or CS increased plant height

Table 2 Susceptibility of barnyard grass to nicosulfuron and safeners at different treatment levels.

\begin{tabular}{|c|c|c|c|c|}
\hline Treatment $^{\mathrm{a}}$ & Regression equation & $\mathrm{EC}_{50}(\mathrm{mg} / \mathrm{L})$ & Confidence interval (mg/L) & $R$ \\
\hline NS & $y=0.9022+3.0267 x$ & 22.59 & $20.71-24.64$ & 0.9973 \\
\hline NS + IE $(2: 1)$ & $y=1.4217+3.3128 x$ & 12.03 & $10.49-13.79$ & 0.9923 \\
\hline $\mathrm{NS}+\mathrm{IE}(4: 1)$ & $y=1.5833+2.9496 x$ & 14.40 & $10.38-19.98$ & 0.968 \\
\hline NS + IE (8:1) & $y=1.9172+2.7874 x$ & 12.76 & $10.36-15.72$ & 0.9829 \\
\hline $\mathrm{NS}+\mathrm{CS}(2: 1)$ & $y=1.9492+2.5928 x$ & 15.02 & $11.73-19.22$ & 0.9803 \\
\hline $\mathrm{NS}+\mathrm{CS}(4: 1)$ & $y=1.6192+2.8428 x$ & 15.46 & $11.42-20.94$ & 0.9695 \\
\hline $\mathrm{NS}+\mathrm{CS}(8: 1)$ & $y=2.8030+2.0622 x$ & 11.62 & $9.39-14.39$ & 0.9916 \\
\hline
\end{tabular}

${ }^{\mathrm{a}}$ All treatments were applied with a non-ionic surfactant $(0.1 \% \mathrm{v} / \mathrm{v})$.

NS: nicosulfuron; CS: cyprosulfamide; IE: isoxadifen-ethyl.

Table 3 Susceptibility of large crabgrass to nicosulfuron and safeners at different treatment levels.

\begin{tabular}{lllll}
\hline Treatment $^{\mathrm{a}}$ & Regression equation & $\mathrm{EC}_{50}(\mathrm{mg} / \mathrm{L})$ & Confidence interval $(\mathrm{mg} / \mathrm{L})$ & $R$ \\
\hline NS & $y=3.2036+0.9360 x$ & 83.00 & $63.18-109.07$ & 0.9721 \\
NS + IE (2:1) & $y=0.4313+3.4341 x$ & 38.00 & $35.83-40.64$ & 0.9965 \\
NS + IE (4:1) & $y=3.5331+0.8849 x$ & 45.00 & $36.46-56.68$ & 0.9853 \\
NS + IE (8:1) & $y=3.2429+1.2121 x$ & 28.00 & $21.73-36.49$ & 0.9683 \\
NS + CS (2:1) & $y=3.3524+1.0824 x$ & 33.00 & $29.62-37.39$ & 0.9901 \\
NS + CS (4:1) & $y=4.0786+0.8226 x$ & 13.00 & $10.20-17.04$ & 0.9902 \\
NS + CS (8:1) & $y=3.7336+0.8637 x$ & 29.00 & $23.28-36.76$ & 0.9782 \\
\hline
\end{tabular}

${ }^{\mathrm{a}}$ All treatments were applied with a non-ionic surfactant $(0.1 \% \mathrm{v} / \mathrm{v})$.

NS: nicosulfuron; CS: cyprosulfamide; IE: isoxadifen-ethyl. 
to $87 \%-93 \%$ of the non-treated control. At 2 WAT, the plant heights of the waxy maize treated with nicosulfuron plus IE or CS were $88 \%-95 \%$ of the control compared to $81 \%$ for nicosulfuron alone. At 3 WAT, all treatments were not statistically different (Table 4). These findings are similar to those records after treatment with nicosulfuron [2], nicosulfuron plus rimsulfuron [5], foramsulfuron [25] and thifensulfuron-methyl [26]. Both plant height and maize injury showed similar trends.

Weed control varied between treatments (Table 4). At 2 WAT, the best weed control treatment was $90 \%$ for nicosulfuron at $90 \mathrm{~g} / \mathrm{ha}$. Nicosulfuron plus IE or $\mathrm{CS}$ led to lower weed control than nicosulfuron alone. All treatments, except $60 \mathrm{~g} / \mathrm{ha}$ nicosulfuron plus CS, provided greater than $90 \%$ control of weeds at 3 WAT.
Nicosulfuron at $60 \mathrm{~g} / \mathrm{ha}$ plus CS decreased weed control compared to the other treatments, and this may be due to the presence of more developed broadleaf weeds at the time of herbicide application, which may have resulted in less herbicide absorption [27].

The maize grain weight of the weedy control was reduced by $27 \%$ in 2014 and by $23 \%$ in 2015 compared to the weed-free control. Both herbicide safeners were safe for use in the waxy maize crop. Maize grain weights were not significantly different from the weed-free control in both years (Table 5), when nicosulfuron was applied alone or in combination with CS or IE. Maize grain weights after nicosulfuron treatment were significantly higher than those for the weedy control in 2014 for both applied nicosulfuron alone or in combination with CS or IE. In

Table 4 Waxy maize plant height and injury at 1, 2 and 3 WAT with nicosulfuron alone or in combination with IE and CS.

\begin{tabular}{|c|c|c|c|c|c|c|c|c|c|}
\hline \multirow[b]{2}{*}{ Treatment ${ }^{\mathrm{a}}$} & \multirow[b]{2}{*}{$\begin{array}{l}\text { Rate } \\
\text { (g/ha) }\end{array}$} & \multicolumn{2}{|l|}{$1 \mathrm{WAT}$} & \multicolumn{3}{|c|}{2 WAT } & \multicolumn{3}{|c|}{$3 \mathrm{WAT}$} \\
\hline & & $\begin{array}{l}\text { Plant height } \\
\text { reduction } \\
(\% \text { of control })\end{array}$ & $\begin{array}{l}\text { Injury } \\
\text { grade }\end{array}$ & $\begin{array}{l}\text { Plant height } \\
\text { reduction } \\
(\% \text { of control) }\end{array}$ & $\begin{array}{l}\text { Weed } \\
\text { control } \\
(\%) \\
\end{array}$ & $\begin{array}{l}\text { Injury } \\
\text { grade }\end{array}$ & $\begin{array}{l}\text { Plant height } \\
\text { reduction } \\
(\% \text { of control }) \\
\end{array}$ & $\begin{array}{l}\text { Weed } \\
\text { control (\%) }\end{array}$ & $\begin{array}{l}\text { Injury } \\
\text { grade }\end{array}$ \\
\hline NS & 90 & 71 & 3 & 81 & 90 & 2 & 91 & 95 & 2 \\
\hline $\mathrm{NS}+\mathrm{IE}$ & $90+15$ & $87^{*}$ & 1 & $88^{*}$ & 85 & 0 & 98 & 90 & 0 \\
\hline $\mathrm{NS}+\mathrm{CS}$ & $90+15$ & $90^{*}$ & 0 & $92^{*}$ & 85 & 0 & 97 & 90 & 0 \\
\hline NS & 60 & 69 & 2 & 81 & 85 & 1 & 93 & 90 & 1 \\
\hline $\mathrm{NS}+\mathrm{IE}$ & $60+15$ & $91^{*}$ & 0 & $95^{*}$ & 85 & 0 & 103 & 90 & 0 \\
\hline $\mathrm{NS}+\mathrm{CS}$ & $60+15$ & $93^{*}$ & 0 & $94^{*}$ & 70 & 0 & 99 & 70 & 0 \\
\hline
\end{tabular}

NS: nicosulfuron; CS: cyprosulfamide; IE: isoxadifen-ethyl; WAT: weeks after treatment.

Data are combined across two years. Injury grade was evaluated as 0 (no injury) to 4 (complete leaf tissue necrosis) scale. ${ }^{\text {a }}$ All treatments were applied with a non-ionic surfactant $(0.1 \% \mathrm{v} / \mathrm{v}) .{ }^{*}$ Differences between safener-treated plants and the nicosulfuron treatment were significant at $P=0.05$.

Table 5 Effect of different treatments on grain weight when applied at different doses to maize at the 3- to 5-leaf stage.

\begin{tabular}{llll}
\hline \multirow{2}{*}{ Treatment $^{\mathrm{a}}$} & Rate $(\mathrm{g} / \mathrm{ha})$ & 2014 & \multicolumn{2}{c}{ Grain weight $(\mathrm{g})$} \\
\cline { 3 - 4 } $\mathrm{NS}$ & 90 & $185.42 \pm 5.33^{*}$ & $169.65 \pm 30.87$ \\
$\mathrm{NS}+\mathrm{IE}$ & $90+15$ & $186.68 \pm 12.86^{*}$ & $177.22 \pm 20.95^{*}$ \\
$\mathrm{NS}+\mathrm{CS}$ & $90+15$ & $183.70 \pm 12.48^{*}$ & $183.02 \pm 12.53^{*}$ \\
$\mathrm{NS}$ & 60 & $188.50 \pm 12.02^{*}$ & $170.99 \pm 18.40$ \\
$\mathrm{NS}+\mathrm{IE}$ & $60+15$ & $192.72 \pm 17.00^{*}$ & $198.95 \pm 7.83^{*}$ \\
$\mathrm{NS}+\mathrm{CS}$ & $60+15$ & $186.27 \pm 14.30^{*}$ & $198.71 \pm 12.01^{*}$ \\
Weed-free & & $192.61 \pm 22.28$ & $190.32 \pm 12.28$ \\
Weedy & & $140.60 \pm 15.98$ & $145.60 \pm 13.98$
\end{tabular}

NS: nicosulfuron; CS: cyprosulfamide; IE: isoxadifen-ethyl.

${ }^{a}$ All treatments were applied with a non-ionic surfactant $(0.1 \% \mathrm{v} / \mathrm{v}) .{ }^{*}$ Differences between herbicide treatment and the weedy control were significant at $P=0.05$. 
the case of nicosulfuron in 2015, maize grain weight was significantly higher than that of the weedy control for nicosulfuron applied in combination with CS or IE, but maize grain weight was not significantly different from the weedy control, when it was applied alone (Table 5). The reason might be that the two nicosulfuron treatments inhibited waxy maize growth, resulting in lower grain weights. These results were consistent with other studies, where sweet corn hybrid ear lengths and diameters were reduced by primisulfuron and nicosulfuron [4].

\section{Conclusions}

This study is a preliminary evaluation of the herbicide safeners in reducing maize injury from nicosulfuron. These results indicate that $\mathrm{CS}$ and IE reduced growth inhibition caused by nicosulfuron application to waxy maize plants, and increased herbicide activity against weeds. The obtained results may provide a support to enhance crop safety and prolong the activity of nicosulfuron. Further studies will be conducted to evaluate the safener protection mechanisms in maize. Additional research is needed to determine the phytotoxicity of nicosulfuron metabolites and identify which metabolites are predominantly formed.

\section{Acknowledgements}

This work was supported by the Special Fund for Agro-scientific Research in the Public Interest (201203098). The authors would like to thank Huihui Sun and Qianqian Zhi for their assistance in conducting these experiments. The authors also thank the editors and a number of anonymous reviewers for their valuable comments.

\section{References}

[1] Li, M. 2010. "Review and Prospect of Maize Production in the World.” J. Maize Sci. 18 (3): 165-9.

[2] O'Sullivan, J., Sikkema, P. H., and Thomas, R. J. 2000. "Sweet Maize (Zea mays) Cultivar Tolerance to Nicosulfuron." Can. J. Plant Sci. 80 (2): 419-23.
[3] Robinson, D. K., Monks, D. W., and Burton, J. D. 1994. "Effect of BAS-145138, CGA-154281 and Naphthalic Anhydride Seed Treatments on Sweet Maize (Zea mays) Tolerance to Nicosulfuron." Weed Sci. 42 (4): 614-7.

[4] Grey, T. L., Bridges, D. C., Raymer, P., Day, D., and NeSmith, D. S. 2000. "Differential Tolerance of Fresh Market Sweet Corn Cultivars to the Herbicides Nicosulfuron and Primisulfuron." HortScience 35 (6): 1070-3.

[5] O’Sullivan, J., Brammall, R. A., and Bouw, W. J. 1995. "Response of Sweet Maize (Zea mays) Cultivars to Nicosulfuron Plus Rimsulfuron." Weed Technol. 9 (1): 58-62.

[6] Williams, M. M., Pataky, J. K., Nordby, J. N., Riechers, D. E., Sprague, C. L., and Masiunas, J. B. 2005. "Cross-Sensitivity in Sweet Corn to Nicosulfuron and Mesotrione Applied Postemergence." HortScience 40 (6): 1801-5.

[7] Zhang, Q. G., Yang, L. H., Dong, J. G., and Zhang, J. L. 2010. "Study on the Detoxication Effects of Cloquintocet-Mexyl and Dichlormid on Phytotoxicity of Nicosulfuron and Mesotrione on Maize." J. Hebei Agr. Sci. 14 (9): 63-7. (in Chinese)

[8] Gao, X. J., Ma, Y. H., Wang, H. L., Chen, W., and Jia, G. M. 2015. "Detoxication Effects of Three Safeners on Phytotoxicity of Nicosulfuron on Maize." Agrochem. 54 (4): 306-9.

[9] Li, W., Hu, C., Gao, S. M., Feng, L., Wang, X. G., Jing, Q. Y., Liu, B., and Liu, Y. G. 2014. "Preliminary Study on Sensitivity of Different Spring Maize Varieties to Nicosulfuron." Crops 2 (1): 64-9.

[10] Rosinger, C., and Köcher, H. 2007. "Safeners for Herbicides." In Modern Crop Protection Compounds, edited by Krämer, W., and Schirmer, U. Weinheim, Germany: Wiley-VCH Verlag GmbH, 371-97.

[11] Siminszky, B., Corbin, F. T., and Sheldon, Y. 1995. "Nicosulfuron Resistance and Metabolism in Terbnfos and Naphthalic Anhydride-Treated Corn." Weed Sci. 43 (2): 163-8.

[12] Robinson, D. K., Monks, D. W., and Burton, J. D. 1996. "Safening Influence of LAB 145138 on Nicosulfuron, Terbufos and Bentazon Interactions in Sweet Corn (Zea mays)." Weed Sci. 44 (2): 339-44.

[13] Elmore, M. T., Brosnan, J. T., Armel, G. R., Vargas, J. J., and Breeden, G. K. 2015. "Influence of Herbicide Safeners on Creeping Bentgrass (Agrostis stolonifera) Tolerance to Herbicides." Weed Technol. 29 (3): 550-60.

[14] Bernards, M. L., Simmons, J. T., Guza, C. J., Schulz, C. R., Penner, D., and Kells, J. J. 2006. "Inbred Corn Response to Acetamide Herbicides as Affected by Safeners and Microencapsulation." Weed Technol. 20 (2): 458-65.

[15] Nelson, E. A., and Penner, D. 2006. "Reduction of 

and Affect Weed Control

Isoxaflutole Injury to Corn (Zea Mays) with Herbicide Safeners and Water-Repellent Adjuvants." Weed Technol. 20 (4): 999-1003.

[16] Schulte, W., and Köcher, H. 2009. "Tembotrione and Combination Partner Isoxadifen-Ethyl-Mode of Herbicidal Action.” Bayer Crop Sci. J. 62 (1): 35-52.

[17] Yang, C. H., Dong, L. Y., Li, J., and Moss, S. R. 2007. "Identification of Japanese Foxtail (Alopecurus japonicus) Resistant to Haloxyfop Using Three Different Assay Techniques." Weed Sci. 55 (6): 537-40.

[18] Kotoula-Syka, E., and Hatzios, K. K. 1996. "Interactions of Tribenuron with Four Safeners and Piperonyl Butoxide on Corn (Zea mays)." Weed Sci. 44 (2): 215-8.

[19] Ekler, Z., and Stephenson, G. R. 1991. "Comparative Effectiveness and Mode of Action of Safeners for Chloroacetamide Herbicides in Maize Seedlings." Zeitschrift fur Naturforschung C 46 (9-10): 828-35.

[20] Sprague, C. L., Penner, D., and Kells, J. J. 1999. "Enhancing the Margin of Selectivity of RPA 201772 in Zea mays with Antidotes." Weed Sci. 47 (5): 492-7.

[21] Elmore, M. T., Brosnan, J. T., Armel, G. R., Vargas, J. J., and Breeden, G. K. 2016. "Herbicide Safeners Increase Creeping Bentgrass (Agrostis stolonifera) Tolerance to Pinoxaden and Affect Weed Control." Weed Technol. 30
(4): 919-28.

[22] Cummins, I., Bryant, D. N., and Edwards, R. 2009. "Safener Responsiveness and Multiple Herbicide Resistance in the Weed Black-Grass (Alopecurus myosuroides)." Plant Biotechnol. J. 7 (8): 807-20.

[23] Bayer Crop Science. 2011. "Puma Product Label." Bayer Crop Science LP. Publication No. US04514245D, Research Triangle Park, NC.

[24] Zhang, J. W., Zheng, L., Jäck, O., Yan, D. Y., Zhang, Z. J., Gerhards, R., and Ni, H. W. 2013. "Efficacy of Four Post-Emergence Herbicides Applied at Reduced Doses on Weeds in Summer Maize (Zea mays L.) Fields in North China Plain.” Crop Prot. 52: 26-32.

[25] Diebold, S., Robinson, D., Zandstra, J., O'Sullivan, J., and Sikkema, P. 2003. "Sweet Corn (Zea mays) Cultivar Sensitivity to AEF1303601." Weed Technol. 17 (1): 127-32.

[26] Soltani, N., Sikkema, P. H., and Robinson, D. E. 2005. "Sweet Corn Hybrid Responses to Thifensulfuron-Methyl." HortScience 40 (5): 1381-3.

[27] Hennigh, D. S., Al-Khatib, K., Currie, R. S., Mitchell, R. T., Patrick, W. G., Phillip, W. S., and Mark, M. C. 2010. "Weed Control with Selected Herbicides in Acetolactate Synthase-Resistant Sorghum.” Crop Prot. 29 (8): 879-83. 